\title{
A Cultural Political Economy of Crisis Recovery: (Trans-)National Imaginaries of 'BRIC' and Subaltern Groups in China
}

Ngai-Ling Sum, Politics, Philosophy and Religion Department, Lancaster University

To be published in Economy and Society 2013, 42 (4): 543-570

DOI: $10.1080 / 03085147.2012 .760348$

\section{Introduction}

This article explores discourses and practices of crisis recovery from a cultural political economy (hereafter $\mathrm{CPE}$ ) perspective. Many recent accounts of 'crisis recovery' and the imaginaries on which they draw are national- and state-focused, especially when referring to government stimulus or austerity packages. In contrast, this article employs CPE to redirect attention to the imaginaries used by (trans-)national and/or intergovernmental forces in identifying and promoting another road to recovery. Specifically, it focuses on how entities such as international investment banks, economic strategists, international organizations, think tanks, intergovernmental agencies, and business media, have (re-) imagined the role of the 'BRIC' (Brazil, Russia, India, China) economies as drivers of recovery in the context of financial crises in the USA and Europe. The article has five parts. Part one briefly addresses the rapidly developing literature on 'cultural economy' and the ways in which the proposed CPE approach can add to a micro-macro understanding of (financial) (dis-)orders. Part two applies this approach to the roles of nodal (trans-)national forces in making, negotiating and circulating 'BRIC' as an economic imaginary. It argues that this involves constructions of 'hope'/'strength' in three overlapping moments: an investor narrative, then an investorconsumer tale, and, since 2009, an investor-consumer-lender story. The changing BRIC imaginary has both transnational and national significance and its resonance depends not only 
on developments in the 'financial' and 'real' economies but also on specific discourses, practices, and knowledge technologies. Part three addresses the structural/material contexts in which the BRIC discourses were popularized by private and public sector actors in response to the continuing financial crisis that became visible in 2007. In this conjuncture, the BRIC economies were identified as sites that could facilitate 'economic recovery'. This imagined recovery was made more credible when the BRIC countries developed their own stimulus packages. China was seen as leader of the pack here and its large national package was described by one international economist (Lardy) as 'gold standard' (see below). Part four examines how this package intensified some deep-rooted tensions in central-local relations. More specifically, it posed tremendous fiscal challenges for local authorities, which rely heavily on land as a source of revenue and mortgage loans. The resulting intensified commodification of land has further inflated the 'property bubble' and stimulated more land dispossession/grabbing. This harms China's subaltern groups in various ways, illustrated below by the cases of 'house slaves' and the plight of migrant workers' children. Though some measures have been taken to dampen the property market, their impact has been limited and social unrest continues. Part five comments on CPE's contribution to understanding the micro-power relations involved in constructing hope as well as on some macro-structural issues involved in attempts to stimulate recovery.

\section{Towards a Cultural Political Economy of Imagined Recovery}

CPE partly overlaps with the rapidly-developing literature on 'cultural economy' found in the work of Callon (1988), MacKenzie et al (2007), Pryke and du Gay (2007), and others. Their post-structural concern with the cultural orderings of the economy highlights the importance of micro-level devices in (re-)producing market knowledge and the performative effects of economic imaginaries in creating/changing subjectivities. The emphasis on 'how' knowledge is created and performed in the market and reaches into everyday life has gained much 
academic attention. Regarding financialization, for example, studies include: (a) knowledging technologies in identifying, calculating and marketing risk as profit (e.g., de Goede 2004); (b) the performative qualities of financial theories and calculating techniques such as the BlackScholes model in constituting and altering markets and market behaviour (e.g., MacKenzie 2004 and 2006); and (c) the construction and cultivation of financial subjects and agency (e.g., Aitken 2007).

While this literature has advanced understanding of the micro-foundations and technologies in building (financial) markets, it has been criticized for reinforcing and reifying the power of rational calculation as articulated by neoclassical economics and for downplaying the political nature of the market (see the criticisms in Slater 2002; Pryke and du Gay 2007; Montgomerie 2008). This critique is reiterated by Paterson who, with Best (2010), promoted 'cultural political economy' as a 'field of study' that seeks to bring politics into the cultural economy literature (Descheneau and Paterson 2012: 67). This contribution is useful in its own terms but can add little to 'cultural economy' or 'political economy' more generally unless more is said on: (a) the processes and mechanisms of politicization; (b) the role of power relations, especially in privileged sites of capital accumulation, in framing discourses; (c) the role of nodal discursive networks in shaping and being shaped by (financial) market building; (d) the intertwining of the macro-structural imperatives of global capitalism, economic narratives and more micro-social relations; and (e) the interaction between material structure and agencies in uneven and contested remaking of social relations. In this regard, the CPE approach developed here (as opposed to 'cultural political economy' as a broad field of study à la Best and Paterson) explores the micro-macro interface between the discursive and material moments involved in reproducing and remaking capitalism (Sum 2005, Jessop and Sum 2006; Sum 2010; Sum 2011; Sum and Jessop 2006; Sum and Jessop 2013). 
Accordingly, this theoretical agenda highlights the articulation of the more discursive moments (including subjectivities, identities, economic and political categories, knowledge production, modes of calculation, and structures of feeling) of economic-political relations as well as their structural features (including social forms, their institutional mediations, contradictions, crisis-tendencies, and class relations). These discursive-material interactions become more visible during crisis conjunctures when sedimented social relations are repoliticized. Actors seek to interpret the crisis as a basis for crisis management and/or recovery, including developing and justifying stimulus packages, austerity programmes, new investment sites, etc. This article applies CPE to the emergence of the 'BRIC' imaginary as a possible new path towards crisis recovery. As objects of 'hope'/'strength', the BRIC quartet were imagined in three overlapping moments. It was first identified during the post-9/11 security crisis in 2001 and, in the wake of the 2007 financial crisis, it has been re-imagined as well as translated into different rationalities and material practices. This has involved what neo-Foucauldians call knowledging technologies (Dean 1999; Miller and Rose 2008) as well as processes of selection, recontextualization, circulation and sedimentation.

The CPE approach proposed here examines not only 'how' knowledge is constructed; but also investigates 'when', 'who', and 'what' issues. These questions point beyond discursive technologies to the role of nodal discursive networks of individual and institutional actors in remaking social relations. For present purposes, this agenda can be re-specified as follows: (1) when does a particular economic imaginary (e.g., BRIC) and its related discursive networks begin to gain credence; (2) who gets involved in the discursive networks that construct and promote objects of 'hope'/‘strength'; (3) what additional ideas and practices are selected and drawn upon to recontextualize and hybridize the referents of these objects; (4) 
what governmental knowledging technologies are involved in constituting subjectivities and identities; (5) how do these imaginaries, subjectivities, and identities become normalized, translated and negotiated and, in particular, how do they change everyday financial practices or enter the policy field; (6) how far and in what ways do these changes have uneven impacts across different sites and scales (e.g., the lives of subaltern groups); and (7) how are they being negotiated and/or resisted in the rebuilding of social relations $?^{1}$ Adequate answers require attention to discourse, power and structural materialities. This article explores these questions through the case of the BRIC imaginary and its differential appropriation and uneven impact especially at local sites.

\section{The Construction of Hope/Strength: Three Moments in the Making of 'BRIC' ${ }^{2}$}

'BRIC' discourse builds on the idea of 'emerging markets'. This latter notion was coined in 1981 by fund manager Antoine van Agtmael of Emerging Markets Management. It mapped selectively some large 'Third World' and post-socialist economies as sites of 'new opportunities' with 'high risks' but potentially high returns (Sidaway and Pryke 2000). 'BRIC' is a subset of the 'larger emerging markets' and was identified by major investment banks and, later, international organizations as having high-growth potential and, hence, as a suitable target for increased investment after September 11 in 2001. As a set of hope imaginaries, it emerged through three overlapping moments, i.e., as an investor narrative, an investor-consumer tale, and, an investor-consumer-lender story. Shifting sets of nodal actors were involved at each moment as agents responded to new crisis symptoms emerged by elaborating new BRIC imaginaries. This involved the production of BRIC knowledge based on micro-level instruments (e.g., reports, books, and investment funds) and governing technologies and was oriented to creating new capacities for individual and collective action. 
Inspired by affect studies (e.g., Massumi n.d.; Connolly 2002), Chaput reads such rhetorical moments as discursive spaces that are shot through with the affective energy of capitalism. This energizes common-sense beliefs and means that individual and collective decisions are not governed purely by rational calculation about self-interest but are also emotionally charged (Chaput 2010: 4-8). ${ }^{3}$ This casts interesting light on the role of the BRIC imaginaries in framing, energizing, and governing the desires and strategies of crisis recovery.

Table 1 The Production of 'Hope'/'Strength': Three Overlapping Moments in the

\section{Production of 'BRIC' Knowledge}

\begin{tabular}{|c|c|c|c|}
\hline Moments & Major Actors/Institutions & $\begin{array}{l}\text { Major Discourses and } \\
\text { Knowledge Instruments }\end{array}$ & $\begin{array}{l}\text { Knowledging } \\
\text { Technologies }\end{array}$ \\
\hline $\begin{array}{l}\text { Moment } 1 \\
2001- \\
\text { present } \\
\text { 'BRIC' as } \\
\underline{\text { an }} \\
\underline{\text { investor }}\end{array}$ & $\begin{array}{l}\text { International investment } \\
\text { banks (e.g., Goldman } \\
\text { Sachs) } \\
\text { Chief Economist (e.g., } \\
\text { Jim O’Neill) \& } \\
\text { colleagues; fund } \\
\text { managers, sales teams, } \\
\text { financial journalists, } \\
\text { rating agency, etc. }\end{array}$ & $\begin{array}{l}\text { - } 2001 \text { Invented the } \\
\text { category in the report on } \\
\text { Building Better Global } \\
\text { Economic BRICs } \\
\text { - } 2003 \text { Research report on } \\
\text { 'Dreaming with BRICs: } \\
\text { The Path to 2050' } \\
\text { - Other reports, books, } \\
\text { webtours, indexes, etc. } \\
\text { (see also table 2) } \\
\text { BRIC investment funds } \\
\text { (see also table 3) }\end{array}$ & $\begin{array}{l}\text { Technologies of } \\
\text { identification and } \\
\text { achievement }\end{array}$ \\
\hline $\begin{array}{l}\text { Moment } 2 \\
2004- \\
\text { present } \\
\frac{\text { 'BRIC' as }}{\frac{\text { an }}{\text { investor- }}} \\
\underline{\text { consumer }} \\
\underline{\text { story }}\end{array}$ & $\begin{array}{l}\text { Economists, investment } \\
\text { consultants, business } \\
\text { media (Bloomberg, The } \\
\text { Economist, CNN, blogs, } \\
\text { etc.), international } \\
\text { organizations (e.g., World } \\
\text { Bank, IMF) }\end{array}$ & $\begin{array}{l}\text { - Decoupling theses } \\
\text { (The trans-Atlantic } \\
\text { economies are in } \\
\text { recession due to the } \\
\text { subprime crisis and its } \\
\text { fallout. Other regions, } \\
\text { especially the BRIC, } \\
\text { continue to grow during } \\
\text { this downturn - strong } \\
\text { consumption) } \\
\text { 'Decoupling 2.0' article } \\
\text { (The Economist) }\end{array}$ & $\begin{array}{l}\text { Technology of } \\
\text { identification }\end{array}$ \\
\hline $\begin{array}{l}\text { Moment } 3 \\
\text { Late } 2008- \\
\text { present } \\
\text { 'BRIC' as } \\
\underline{\text { an investor- }} \\
\underline{\text { consumer- }}\end{array}$ & $\begin{array}{l}\text { International } \\
\text { organizations ( } W B, I M F \text {, } \\
G 20, \text { BRIC Summits, } \\
\text { etc.), national leaders, } \\
\text { foreign policy analysts } \\
\text { and mass media }\end{array}$ & $\begin{array}{l}\text { - Subscribing to IMF } \\
\text { Special Drawing Rights } \\
\text { (e.g., USD 50 bn by } \\
\text { China in 04/09/09) } \\
\text { - Shifting global economic } \\
\text { and political governance } \\
\text { (e.g., 'multipolar world' }\end{array}$ & $\begin{array}{l}\text { Technology of } \\
\text { agency }\end{array}$ \\
\hline
\end{tabular}




\begin{tabular}{|l|l|l|l|}
\hline lender story & from $G 8$ to $G 20)$ & \\
\hline
\end{tabular}

(Source: Author's own compilation)

3.1 First moment in the BRIC imaginary, 2001- present: investor story

Contrary to the fuzzy origins of most discursive objects, the BRIC idea has a clear starting point. It began with the invention of the idea of 'BRIC' by a major investment bank -Goldman Sachs. Influenced by the security crisis of 9/11 and China's entrance into the WTO in 2001, Jim O'Neill, then Goldman Sachs' Chief Economist, interpreted the destruction of the World Trade Centre as signifying that further progress in globalization could no longer rely on US leadership and, indeed, must look beyond the northern-western world (Tett 2010). This diagnosis of the demise of American dominance and the emergence of global China (and other emerging markets) prompted the Goldman team to identify some useful 'non-western others' with high growth potential. By 30 November 2001, these 'others' were baptised as the 'BRIC' in Goldman Sachs Global Economic Paper No. 66, which was titled Building Better Global Economic Brics.

Based on a mathematized model on demographic trends and productivity rates, it forecast their combined GDP growth rates would range between 9 to 14 percent in 2010. This new body of knowledge identified and constructed BRIC as a complementary group of economies that is 'set to grow again by more than the G7' (Goldman Sachs 2001: S.03). Within this group, while China and India were seen as having higher growth rates and emerging as dominant global suppliers of manufactured goods and services, Brazil and Russia would acquire dominance as suppliers of agricultural goods, raw materials, and energy. 
The creation of BRIC as a distinct site for investors initially met with mixed reactions. While Goldman Sachs' corporate clients, who were seeking new markets, liked this construction, banks and investors were more sceptical as the BRIC were deemed vulnerable to political upheavals and falling commodity prices. Nonetheless, O'Neill's team continued to supply their clients with 'hope' based on expectations of high investment returns. In a 2003 report, Dreaming with BRICs: The Path to 2050, two other economists in his team framed BRIC economic dynamics in terms of growth paths spurred by 'ingredients' such as sound macroeconomic policies, low inflation, openness to trade and high levels of education (O’Neill 2012: 34-5). ${ }^{4}$ The team forecast that, by 2050, the BRIC would catch up and become 'emerged' economies. By then, China's gross domestic product could be 30 per cent larger than that of the US; India's could be four times that of Japan; and the figures for Brazil and Russia could be at least 50 per cent bigger than UK GDP. For the team, such achievements would rebalance the world economy with the BRICs' growth offsetting 'the impact of greying populations and slower growth in the advanced economies' (Wilson and Purushothaman 2003:2).

References to catch-up and prospective performance can be seen, in neo-Foucauldian terms, as technologies of identification and achievement in which the BRIC quartet is singled out, made knowable, and visibilized as a coherent set of 'emerging' economies embarking on high-growth paths with great potential for long-term investors (see table 1). These two knowledging technologies supported the 'sales pitch' of Goldman Sachs and other fund managers and financial sales teams, and thereby facilitated the circulation of BRIC as a new 'dream' in this nodal investment network. As neoliberal globalization was consolidated (in part with China's entry into the WTO), more and more corporations and financial organizations were scoping new markets and profitable investment sites. New discursive 
networks, which included corporate executives, investment bankers, fund managers, etc., began to endorse and reinforce the BRIC imaginary as a desirable object of investment and strategic actions. After the 2003 paper, Goldman economists entered what O’Neill described as 'briclife' (Tett 2010) as clients (e.g., Vodafone, BHP Billiton, IKEA and Nissan) swamped their daily routines with enquiries. Indeed, some clients not only imbibed but also actively promoted the BRIC KoolAid as a refreshing object of investment hope and actions. The Goldman team kept this affective space alive by churning out more knowledge products. Between 2001 and 2012, to keep 'briclife' going ${ }^{5}$, it created 21 such products, including reports, fresh forecasts, books, videos, and webtours (in different languages) to inspire hope (see table 2).

Table 2 Major BRIC Knowledge Products Constructed by O'Neill and the Goldman Sachs Team

\begin{tabular}{|c|c|c|}
\hline $\begin{array}{l}\text { Name of the } \\
\text { Knowledge Products }\end{array}$ & $\begin{array}{l}\text { Nature of Product } \\
\text { (Year/Month) }\end{array}$ & $\begin{array}{l}\text { Ways of Constructing Hope and } \\
\text { Strength }\end{array}$ \\
\hline $\begin{array}{l}\text { Building Better Global } \\
\text { Economic BRICs }\end{array}$ & $\begin{array}{l}\text { Report } \\
\text { November } 2001\end{array}$ & $\begin{array}{l}\text { - Invented the BRIC category } \\
\text { - Outlining healthier outlook in BRIC } \\
\text { with a forecast of } 1.7 \% \text { GDP growth } \\
\text { rate }\end{array}$ \\
\hline $\begin{array}{l}\text { Dreaming with BRICs: The } \\
\text { Path to } 2050\end{array}$ & $\begin{array}{l}\text { Report } \\
\text { October } 2003\end{array}$ & $\begin{array}{l}\text { - Mapping out BRIC's GDP growth until } \\
2050 \\
\text { - Postulating BRIC economies could be } \\
\text { larger than G6 in } 40 \text { years' time }\end{array}$ \\
\hline How Solid are the BRICs? & $\begin{array}{l}\text { Forecast } \\
\text { December } 2005\end{array}$ & $\begin{array}{l}\text { - Updating the } 2003 \text { forecast } \\
\text { - Arguing that BRIC grow more strongly } \\
\text { than projection }\end{array}$ \\
\hline $\begin{array}{l}\text { Web Tour: The BRICs } \\
\text { Dream (in English, Arabic, } \\
\text { Chinese and Japanese) }\end{array}$ & $\begin{array}{l}\text { Webtours } \\
\text { May } 2006\end{array}$ & $\begin{array}{l}\text { - A video on the BRIC } \\
\text { - Dreaming about BRIC and the } \\
\text { changing world after } 9 / 11 \\
\text { - Contending China would overtake the } \\
\text { USA in } 2050 \\
\text { - Arguing Growth of the middle classes }\end{array}$ \\
\hline
\end{tabular}




\begin{tabular}{|c|c|c|}
\hline & & $\begin{array}{l}\text { in BRIC and major consumers of cars } \\
\text { and energies }\end{array}$ \\
\hline $\begin{array}{l}\text { India's urbanization: } \\
\text { Emerging opportunities }\end{array}$ & $\begin{array}{l}\text { Report } \\
\text { July } 2007\end{array}$ & $\begin{array}{l}\text { - Framing boom in city life } \\
\text { - Identifying investment opportunities in } \\
\text { urban infrastructure and fast } \\
\text { accumulation of financial assets }\end{array}$ \\
\hline BRICS and Beyond & $\begin{array}{l}\text { Book } \\
\text { November } 2007\end{array}$ & $\begin{array}{l}\text { - Updating the } 2001 \text { report } \\
\text { - Postulating increase in value of BRIC's } \\
\text { equity markets } \\
\text { - Moving beyond BRIC to other } \\
\text { emerging economies (e.g., N-11) }\end{array}$ \\
\hline Interview with Jim O'Neill & $\begin{array}{l}\text { Video } \\
\text { February } 2008\end{array}$ & $\begin{array}{l}\text { - Maintaining BRIC's share of global } \\
\text { GDP as } 15 \% \\
\text { - Advising individual BRIC countries } \\
\text { (e.g., India needs more FDI) } \\
\text { - Arguing for the sustainability of BRIC } \\
\text { - Increasing international role of these } \\
\text { countries }\end{array}$ \\
\hline $\begin{array}{l}\text { Building the World: } \\
\text { Mapping Infrastructure } \\
\text { Demand }\end{array}$ & $\begin{array}{l}\text { Report } \\
\text { April } 2008\end{array}$ & $\begin{array}{l}\text { - Identifying increase demand for } \\
\text { infrastructure } \\
\text { - Arguing China will be the source of } \\
\text { one-half to three-quarter of incremental } \\
\text { demand } \\
\text { - Intensifying pressure on commodity } \\
\text { markets }\end{array}$ \\
\hline $\begin{array}{l}\text { Ten Things for India to } \\
\text { Achieve its } 2050 \text { Potential }\end{array}$ & $\begin{array}{l}\text { Report } \\
\text { June } 2008\end{array}$ & $\begin{array}{l}\text { - Advising on improvement of } \\
\text { governance and the need to control } \\
\text { inflation } \\
\text { - Promoting the liberalization of } \\
\text { financial market } \\
\text { - Supporting improvement for } \\
\text { agricultural productivity }\end{array}$ \\
\hline $\begin{array}{l}\text { BRICs Lead the Global } \\
\text { Recovery }\end{array}$ & $\begin{array}{l}\text { Report } \\
\text { May, } 2009\end{array}$ & $\begin{array}{l}\text { - Arguing BRIC can help to led the } \\
\text { stabilization of the world economy } \\
\text { - Promoting BRIC is one of the driving } \\
\text { forces in the export-driven recovery }\end{array}$ \\
\hline $\begin{array}{l}\text { The BRICs as Drivers of } \\
\text { Global Consumption }\end{array}$ & $\begin{array}{l}\text { Report } \\
\text { August } 2009\end{array}$ & $\begin{array}{l}\text { - Arguing G3 countries face slow and } \\
\text { difficult recovery } \\
\text { - Maintaining that BRIC can contribute } \\
\text { to global domestic demand through } \\
\text { higher consumption }\end{array}$ \\
\hline $\begin{array}{l}\text { The BRICs Nifty 50: The } \\
\text { EM \& DM winners }\end{array}$ & $\begin{array}{l}\text { Report and stock baskets } \\
\text { November } 2009\end{array}$ & $\begin{array}{l}\text { - Stating good consumption and } \\
\text { infrastructural demand from BRIC }\end{array}$ \\
\hline
\end{tabular}




\begin{tabular}{|c|c|c|}
\hline & & $\begin{array}{l}\text { - Identifying two BRIC Nifty } 50 \text { baskets } \\
\text { to help investors to access the BRIC } \\
\text { market }\end{array}$ \\
\hline $\begin{array}{l}\text { BRICs at 8: Strong through } \\
\text { the Crisis, Outpacing } \\
\text { forecasts }\end{array}$ & $\begin{array}{l}\text { Video } \\
\text { March } 2010\end{array}$ & $\begin{array}{l}\text { - BRIC weathered the global crisis } \\
\text { remarkably well } \\
\text { - On pace to equal the } \mathrm{G} 7 \text { in size by } \\
2032\end{array}$ \\
\hline $\begin{array}{l}\text { The Growth Map: Economic } \\
\text { Opportunities of BRICs and } \\
\text { Beyond }\end{array}$ & Book 2012 & $\begin{array}{l}\text { - A sole-authored book by O'Neill in } \\
\text { reviewing the economic opportunities } \\
\text { of BRIC and beyond }\end{array}$ \\
\hline
\end{tabular}

(Source: Author's own compilation based on materials from Goldman Sachs' Idea Website on BRIC)

The 'BRIC' imaginary continued to connect and circulate among economic strategists, investment consultants, and sales teams, etc. Its appeal derived not only from the projection of 'hope'/'strength' of the individual BRIC economies but also from their purported complementarity and profitability as an asset/investment group. Major international banks such as $H S B C$ and other investment banks/hedge funds were bundling stocks/shares/bonds and inventing funds marketed new financial instruments under the BRIC brand, including 4Year MYR HSBC BRIC Markets Structured Investment, Templeton BRIC Fund (Singapore), and the iShares MSCI BRIC Index Fund. In order to motivate investors, consultancies, such as Investment $U$ (2009), narrated these funds as highly investable (see Table 3). Their investability was legitimated in terms of the financial good practices of the fund managers as well as the qualities of the BRIC economies. These practices included: (a) a good risk spread via a broad portfolio (e.g., the iShares MSCI BRIC Index Fund invested in 175 stocks); (b) the placement of funds in bigger BRIC economies, above all China/Hong Kong; (c) investment in giant companies operating in 'strong' lines of business (e.g., telecommunication, resources); and (d) strong profit forecasts based on technical criteria (reversion to a pre-crisis mean) or the charismatic status of the 'emerging market' guru (Mark Mobius from Templeton) who managed one fund.. In neo-Foucauldian terms, this technology of 
investability: (a) (b) normalizes the BRIC as investment sites in contrast to previous worried about risk; (b) identifies BRIC stocks as a novel, important and promising alternative asset class; ; and (c) encourages clients desirous of long-term, above-average profits to invest their money in these economies.

Table 3 BRIC Investment Funds and their Construction of Strength and Profitability

\begin{tabular}{|l|l|l|l|}
\hline $\begin{array}{l}\text { Name of } \\
\text { Recommended } \\
\text { Fund }\end{array}$ & Reasons for Choice & $\begin{array}{l}\text { Breakdown of } \\
\text { ETF* by } \\
\text { Country }\end{array}$ & $\begin{array}{l}\text { Top 10 Components } \\
\text { Consist of Giant Firms }\end{array}$ \\
\hline $\begin{array}{l}\text { iShares MSCI } \\
\text { BRIC Index Fund }\end{array}$ & $\begin{array}{l}\text { A portfolio of about 175 stocks } \\
\text { from the BRIC countries. } \\
\text { Despite a gain in excess of 40\% } \\
\text { year-to-date, the fund is still } \\
\text { down over 30\% over the past } 52 \\
\text { weeks, so valuations are still } \\
\text { not back to pre-crisis levels }\end{array}$ & $\begin{array}{l}\text { China and Hong } \\
\text { Kong: 42\%, } \\
\text { India: 13\% and } \\
\text { Russia: 13\% }\end{array}$ & $\begin{array}{l}\text { China Mobile, Gazprom, } \\
\text { Reliance Industry, Petrobras, } \\
\text { Vale, Itau Unibanco, HDFC } \\
\text { Bank, China Life Insurance, } \\
\text { Lukoil, and Industrial \& } \\
\text { Commercial Bank of China }\end{array}$ \\
\hline $\begin{array}{l}\text { Templeton } \\
\text { Fmerging Markets }\end{array}$ & $\begin{array}{l}\text { The fund is managed by } \\
\text { emerging market guru, Mark } \\
\text { Mobius. Mobius has been with } \\
\text { the Templeton since 1987 and } \\
\text { has blazed the trail for } \\
\text { emerging markets investors }\end{array}$ & $\begin{array}{l}\text { Kong: 23\%, } \\
\text { Brazil: 23\%, } \\
\text { India: 10\%, } \\
\text { Russia: 9\%, } \\
\text { Thailand: 8\%, } \\
\text { Turkey and South } \\
\text { Korea: 7\% each }\end{array}$ & $\begin{array}{l}\text { China and Hong } \\
\text { Akbank, Denway Motors, } \\
\text { Itau Unibanco, Sesa Goa, } \\
\text { Banco Bradesco, Aluminum } \\
\text { Eorp of China and SK }\end{array}$ \\
\hline
\end{tabular}

(Source: Adapted from Invest U 2009 to fit a tabular form)

Energetic financial sales teams and other intermediaries marketed these investment products to potential punters, reaching them through advertisements, glossy brochures, financial journalism, phone-calls, one-to-one meetings, etc. Coupled with the general search for new investment sites and asset classes, the flow of portfolio equity funds into BRIC increased by almost twelvefold between 2002 and 2007. Relatedly, the BRIC had a two-thirds share of all investment in developing countries between 2003 and 2007 (see table 4). Within the BRIC group, China gained most in 2006 and India in 2007. In 2008, however, the global credit 
crunch markedly slowed inflows to the BRIC, apart from China, which received US\$ 3.7 billion net.

Table 4 Net Inflows of Portfolio Equity to the BRIC Economies 2002-2008

(\$ billion)

$\begin{array}{lccccccc}\text { Country } & 2002 & 2003 & 2004 & 2005 & 2006 & 2007 & 2008 \\ \text { China } & 2.2 & 7.7 & 10.9 & 20.3 & 42.9 & 18.5 & 3.7 \\ \text { India } & 1.0 & 8.2 & 9.0 & 12.1 & 9.5 & 35.0 & -15.0 \\ \text { Brazil } & 2.0 & 3.0 & 2.1 & 6.5 & 7.7 & 26.2 & -7.6 \\ \text { Russia } & 2.6 & 0.4 & 0.2 & -0.2 & 6.1 & 18.7 & -15.0 \\ \text { BRIC } & \mathbf{7 . 8} & \mathbf{1 9 . 3} & \mathbf{2 2 . 2} & \mathbf{3 8 . 7} & \mathbf{6 6 . 2} & \mathbf{9 8 . 4} & \mathbf{- 3 3 . 9} \\ \text { Developing Countries } & \mathbf{5 . 5} & \mathbf{2 4 . 1} & \mathbf{4 0 . 4} & \mathbf{6 8 . 9} & \mathbf{1 0 4 . 8} & \mathbf{1 3 5 . 4} & \mathbf{- 5 7 . 1}\end{array}$

(Source: Adapted from World Bank, Global Development Finance 2008 and 2010)

3.2 Second moment in the BRIC imaginary, 2004-present: investor-consumer story

The BRIC story developed a consumption subplot from the mid-2000s. This was also started by the Goldman team, which published a report on The BRICs and Global Markets: Crude, Cars and Capital in 2004. It identified the increasing consumption potential of their 'emerging middle classes', especially in terms of demand for commodities, consumer durables and capital services. This BRIC 'dream' was echoed by economic strategists such as Clyde Prestowitz. A former Reagan Administration official, Prestowitz relayed this 'dream' to a wider policy audience through his book, Three Billion New Capitalists, which projected that, by 2020, '... the annual increase in dollar spending by the BRIC will be twice that of the G6' (2005: 227). 
This BRIC-as-consumer story gained more weight as the financial crisis became visible with the collapse of the U.S. sub-prime market in 2007. The spread of wide and deep contagion effects energized the policy communities to seek new signs of 'hope' and objects of recovery. Amongst many such objects (e.g., Green New Deal), the pre-existing BRIC story was reworked to include a consumption dimension. This second moment in the BRIC imaginary (see table 1) attributed a new 'locomotive role' to the BRIC on the grounds that their consumer-led demand would defer recession and offer recovery possibilities for recessionridden advanced economies.

This narrative was enthusiastically circulated by economists, (business) media (e.g., Bloomberg, Newsweek, Wall Street Journal, and CNN) and international organizations (e.g., IMF) in terms of the 'decoupling thesis'. This asserted that the BRIC economies could expand on the basis of their own investment and consumption, despite recession in the USA and other advanced economies. Jim O'Neill was reported on Bloomberg as saying that 'the BRIC consumer is going to rescue the world' (Marinis 2008) and 'since October 2007, the Chinese shopper alone has been contributing more to global GDP growth than the American consumer' (Mellor and Lim 2008). This thesis can be interpreted as a redeployment of the technology of identification in which the BRIC engine was seen as a 'decoupled' object with autonomous consumption power that could save the world from recession.

Reinforcing O'Neill's contribution, this story was popularized by nodal discursive networks of top investment advisors (e.g., Peter Schiff) and fund managers (e.g., Todd Jacobson from Lord Abbett) (Shinnick 2008; Lordabett.com 2009) in the mass and Internet media. For example, Peter Schiff, author and President of Euro-Pacific Capital Inc, made a strong case 
that was echoed in many YouTube videos, blogs, articles, and news items. A typical statement, from his book, Little Book of Bull Moves in Bear Markets, declared:

"I'm rather fond of the word decoupling, in fact, because it fits two of my favorite analogies. The first is that America is no longer the engine of economic growth but the caboose. [The second] When China divorces us, the Chinese will keep 100\% of their property and their factories, use their products themselves, and enjoy a dramatically improved lifestyle." (Schiff 2008: 41).

The 'decoupling thesis' faced a mixed reception. Some financial analysts, economists and international/regional organizations, such as the World Bank and Asia Development Bank, noted a contraction rather than decoupling of trade. For example, in April 2008, citing reduced exports, the World Bank lowered its China growth forecast to 6.5 per cent. A different view was expressed in June 2008, when the IMF released Convergence and Decoupling. This study argued that decoupling could co-exist with integration. Globalization since 1985 has stimulated greater trade and financial integration and this, in turn, has created tighter coupling of business cycles among countries with similar per capita incomes. But it also cited historical evidence that some (groups of) countries have decoupled from the broader global economy at certain periods.

Despite this mixed reception, the decoupling thesis continued to circulate and resonate. As Jim O’Neill himself noted in Newsweek in March 2009:

'Who said decoupling was dead? The decoupling idea is that, because the BRICs rely increasingly on domestic demand, they can continue to boom even if their most 
important export market, the United States, slows dramatically. The idea came into disrepute last fall, when the U.S. market collapse started to spread to the BRICs, but there's now lots of evidence that decoupling is alive and well' (O'Neill 2009).

This was echoed on 21 May 2009 by The Economist magazine in its comment on 'Decoupling 2.0'. This updated thesis re-interpreted decoupling as 'a narrower phenomenon, confined to a few of the biggest, and least indebted, emerging economies', such as China and India. These economies purportedly had strong domestic markets and prudent macroeconomic policies and also enjoyed growing trade among themselves. Thus the BRICdecoupling thesis was limited to China and, to a lesser extent, India. These now became 'useful consumers' thanks to their large foreign exchange reserves, buoyant fiscal positions and financial stimulus packages. In November 2009, after its previous pessimistic forecast, the World Bank raised its 2010 economic forecast for China's GDP growth to 8.4 per cent. These economies offered 'hope' through their solid investment markets, robust consumption from their rising middle classes, and relative large stimulus packages (see table 5).

This narrowing of BRIC was reinforced within the policy circuit by Roger Scher in the Foreign Policy Blogs Network. Questioning Russian strength, he asked whether the story was now 'From BRIC to BIC ... or Even IC??'. Marc Chandler (2009), a prominent foreign exchange market analyst with Brown Brothers Harriman, echoed this and suggested relabeling the BRIC as CRIB. This foregrounding of China resonated with an earlier view of Deutsche Bank Research's Markus Jaeger, who described China as being 'in a class of its own' within the BRIC group (2008).

3.3 Third moment in the BRIC imaginary, 2008-present: investor-consumer-lender story 
Since late 2008, this revised decoupling thesis has provided the basis for the third moment of the BRIC story (see table 1). As the crisis in developed countries deepened and reinforced the search for 'hope' or objects of recovery, more attention went to the BRIC quartet's geopolitical significance. Policy makers, international organizations, think tanks, foreign policy analysts, etc. warmed to the affective ecological space of the BRIC imaginary (see above). Foreign policy rhetoric such as 'the rising power of BRIC', 'emergence of a multipolar world order' and 'post-American world' filled policy papers and media reports. These new geopolitical imaginaries became more credible when Russia held the first BRIC Leaders' Summit in Yekaterinburg in June 2009. This new layer of the BRIC imaginary was enhanced by subsequent summits hosted by Brazil, China and India in April 2010, April $2011^{6}$ and March 2012. They operated (partly) as arenas for the BRIC leaders to perform and project their capacity as a bloc as well as to discuss their future cooperation in trade, investment and finance (despite their differences and competition).

BRIC Summits apart, the IMF and G20 became important sites in which attention turned to the recovery potential of BRIC's lending capacities. For example, at the G20 meeting in London in April 2009, the then UK Prime Minister, Gordon Brown, who was coordinating an IMF rescue package for the global economy, called for support from reserve-rich countries such as China. In response to demands to diminish the dollar's international reserve role, a new loan mechanism was proposed based on an increased Special Drawing Right (SDR) allocation, which amounted to USD 250 billion. To this end, China pledged USD 50 billion, and Russia, Brazil and India each promised USD 10 billion. As the debt crisis deepened in the Eurozone in 2010, the IMF renewed its call for a firewall against 'southern contagion' in March 2012. It proposed a Euro bailout fund of USD 430 billion. Risking domestic criticism for lending to countries with higher per capita GDP than themselves, China eventually agreed 
to contribute USD43 billion and Russia, Brazil and India committed to USD10 billion each in June. This was justified as protecting their own economies from contagions as well as gaining power in the IMF's governance structure (e.g., more voting rights, membership in the executive broad, inclusion of the Chinese Renminbi in the SDR basket, etc.).

These newly-created lending mechanisms symbolically (re-)affirmed the growing economic and political capacity of the BRIC quartet via: (a) the developed economies' recognition that they should be part of the solution to crisis management by subscribing to SDR-denominated bonds and bailout funds; (b) their bargaining power in pushing for changes in the IMF's governance structure; and (c) their specific demand for an uplift from 5 to 7 per cent of total voting shares in the IMF. Despite these signs of 'hope'/'strength' in making a 'multipolar'/'post-American' world, some observers questioned whether these new arrangements would challenge dollar hegemony (e.g., Kelly 2009) and whether BRIC might just become a 'non-western body ... funnelling money to the west' (Chardhuri 2012) to facilitate the recovery of finance capitalism.

In short, these three overlapping moments of (negotiated) construction of 'BRIC' discourses and practices (and their continued affective and cognitive reworking) have helped to circulate, sediment, and naturalize BRIC as a multi-layered object of 'hope'. Each moment in the development of the BRIC narrative has had performative effects: the BRIC economies have graduated from being 'emerging markets' to 'emerging global power' with new hopes invested in them, new practices developed, and new self-identities created. This discursive shift illustrates what neo-Foucauldians regard as a technology of agency (Cruikshank 1999), based on the coexistence of participation and control, this time, in the international arena (see table 1). The BRIC has been encouraged to participate as a 'we' in the new 'multipolar world 
order' but this is associated with efforts to steer the manner of their engagement, e.g., as consumption engines, lenders to the IMF, and so forth. They thereby acquire larger roles in crisis management especially in the reframing of the post-crisis neoliberal global agendas with the BRIC running some symbolic, rather than practical, sideshows such as the creation of BRIC local-currency credit lines (Wheatley 2011) and internationalization of the Chinese Renminbi without full convertibility.

This three moments in the remaking of the BRIC regime as object of 'hope' were created/negotiated/circulated by (trans-)national discursive networks (e.g., investment banks, economic strategists, think tanks, business journals, political leaders, international organizations, etc.). They formulated, prioritized, and sedimented narratives and identities (e.g., 'decoupling thesis' and 'IMF lenders') that drew on the affective energy of capitalism as well as rational calculation. Knowledging technologies of identification, achievement, investability and agency portrayed BRIC (especially China) as a cathectic object of horizonexpanding, crisis-transcending hope that opened the prospects of increased returns on investment, growing consumer demand, new sources of loans, and even, on these bases, global recovery. The making of this hope space is far from a smooth and seamless process. The discursive boundary has been constantly challenged and reinterpreted by other actors who have emphasized the incoherent, discrepant and even 'hopeless' nature of the hegemonic BRIC discourse. Some global market strategists and economists asked why some emerging economies were excluded (e.g., South Korea) and others included (Russia). Some foreign policy analysts question the coherence of the quartet, leading one to use 'BRIC-à-Brac' to convey their heterogeneous nature (Drezner 2009). ${ }^{7}$ More prosaically, others warned of the potential 'BRIC bubble' (e.g., Sharma 2012) and one contrarian re-phrased the BRIC 
acronym as 'bloody ridiculous investment concept' (Business Insider 2011), suggesting that those who entered this market should abandon hope.

Conversely, at the national level, BRIC discourse has been appropriated to promote new and positive collective imaginaries. In India, the discourses of 'Chindia' (Ramesh 2005; Sheth 2007) have been linked to the 'BRIC' imaginary since 2005. In Russia and Brazil, official BRIC narratives are used to project their images as 'rising global players' (e.g., Lula 2011). In the Sinophone world, the appropriation of the term 'BRIC' is more complicated. It has been translated as 'bricks' and was reframed, initially by Taiwan's Business Weekly magazine (No. 901-4), as 'the four golden brick countries'. It appeals to China's nationalist project, which narrates China as a nation regaining international 'greatness-at-last' after a 'century of humiliation'. The 'golden' metaphor helps to signify a 'shining brick' eager to reenter the world stage. One among many 'proofs' is China's self-narration of it being the 'second largest economy in the world' with large gold and forex reserves that could boost global growth.

\section{Structural/Material Contexts of the BRIC Discourses and China's 'Gold Standard' Stimulus Package}

The intensification of the BRIC imaginary is not only a rhetorical process. It is related to the widening and deepening of neoliberal financialization since the 1990s in the name of free markets and financial innovation. The growth of finance-dominated accumulation fuelled the creation of new investment products as well as powerful stock, credit and housing booms that ended in crises. Governments in developed countries put together various financial bailouts and austerity measures that resulted in further support for the financial industry, more 
unemployment and threats to society (Crotty 2009). The deep-rooted and contradictory nature of this epoch has led to an energetic search for new horizons of action and new objects such as BRIC were imagined, especially during the above-noted second and third moments. The BRIC economies, notably China, were repeatedly invoked as investment-consumer and, later, as lender sites that could alleviate the recession and facilitate global economic recovery. In 2008, this imagined recovery was made more convincing and materially credible by the BRIC governments' moves to launch stimulus packages according to their domestic circumstances and place in the world market. According to ILO country reports (2009a-c), China invigorated its economy with a vast infrastructural stimulus package amounting to USD 586 billion. India committed USD 9 billion in stimulus and reduced some excise duties. Brazil announced a USD 20 billion fiscal stimulus and made cut interest rates several times. Russia proposed a USD 62.5 billion Anti-Crisis Programme with numerous measures to upgrade its workforce (see table 5).

Table 5 BRIC’s Stimulus Packages During the Financial Crisis 2008-9

\begin{tabular}{|l|c|c|}
\hline \multicolumn{1}{|c|}{ Country } & Amount (billion USD) & Percentage of GDP \\
\hline China & 586 & 15.0 \\
\hline India & 9 & 0.8 \\
\hline Brazil & 20 & 1.2 \\
\hline Russia & 62.5 & 4.1 \\
\hline
\end{tabular}

(Sources: On China (ILO 2009a: 1); on India (Kannan for ILO 2009: 3); on Brazil (ILO 2009b: 2); on Russia (ILO 2009c: 2))

China was seen as the leader in this bloc in terms of the size of its package (15 percent of its GDP) both at home and abroad. Domestically, it was intended to maintain its 8 percent growth rate as exports and investment fell with the onset of the crisis. Internationally, it was a 
way to alleviate the global crisis thanks to its 'fast and vast investment'. When this package was announced in the G20 meeting in São Paulo in November 2008, it was widely welcomed. For example, it was reported in Reuter that Nicolas Lardy, a China expert and senior fellow at the US-based Peterson Institute for International Economics, described it as 'the gold standard on the stimulus package. It was early, large, and well-designed and it's already gotten very substantial results' (Baldwin 2009). A study by Song (2010) of the New York Times' coverage of the relevant measures between 20 January and 31 March 2009 showed that they were depicted as 'genuine efforts to stimulate the world economy' and led to a more positive reassessment of China's role in the global community. However, from a CPE viewpoint, such positive responses from global players to the stimulus package may not match the everyday experience of ordinary people at national or local level in the BRIC countries. Concentrating on China, the next section examines how this 'gold-standard' package intensified some deep-rooted structural tensions within its political economies.

\section{China's Stimulus Package, Land-Based Finance and the Subaltern Groups}

With the onset of the financial crisis and economic recession in advanced economies, the Chinese central government stimulated its economy by providing support for ten major industrial sectors (e.g., steel, shipbuilding, electronics, petrochemical, etc.), building infrastructural projects (e.g., high speed rail, electric grids), boosting consumer spending, developing the rural economy, and encouraging education and housing. The aim was to maintain GDP growth at ' 8 percent' - a rate that is theoretically the minimum required to create enough jobs to maintain social stability as well as show the world that the 'Chinese brick is rising'. Although the stimulus package was well-received at the global level, centrallocal relations in China itself have been aggravated by its mode of financing. 
Based on practices since the late 1990s, central government funded around one third of this package; the rest was to come from municipal-local governments, governmental ministries, and state-owned enterprises (see table 6). To facilitate this funding, the central government loosened its credit policies, and encouraged state-owned banks to lend. When these measures were communicated to the ministries and local (including provincial, city, prefecture and county) governments, they welcomed this opportunity to get approval for pet projects (e.g., high-speed trains and dams) (Naughton 2009). Under the prevailing central-local fiscal arrangements, local governments must provide matching funds. This is hard because (a) they are expected to channel 60 per cent of their revenue to Beijing; (b) the economic downturn reduced business taxes; and (c) they have no formal mandate to borrow money without central government approval. ${ }^{8}$ This produced a funding gap. Thus a 2009 National Audit Office survey reported that local governments in 18 provinces were failing to provide the expected level matching funds, with the poorest performing province sending only 48 per cent of the amount due (Xi et al., 2009).

Table 6 The Central-Local Government's Share of the Stimulus Package and Sources of Finance in China 2008-2010

\begin{tabular}{|c|c|c|c|}
\hline $\begin{array}{l}\text { Level of } \\
\text { Government }\end{array}$ & $\begin{array}{l}\text { Amount (in } \\
\text { Trillion RMB) }\end{array}$ & $\begin{array}{l}\text { Percentage of } \\
\text { Total }\end{array}$ & Major Sources of Finance \\
\hline $\begin{array}{l}\text { Central } \\
\text { government }\end{array}$ & 1.2 & 29.5 & $\begin{array}{l}\text { - Direct grants } \\
\text { - Interest-rate subsidies }\end{array}$ \\
\hline $\begin{array}{l}\text { Local } \\
\text { governments }\end{array}$ & 2.8 & 70.5 & $\begin{array}{l}\text { - Loan-based finance } \\
\text { - Policy loans } \\
\text { - Local government bonds issued } \\
\text { by the central government (around } \\
200 \text { billion RMB) }\end{array}$ \\
\hline
\end{tabular}




\begin{tabular}{|l|l|l|}
\hline & $-\begin{array}{l}\text { Corporate bonds (130 billion } \\
\text { RMB were issued in Q4 2008) }\end{array}$ \\
- & $\begin{array}{l}\text { Medium-term notes (25 billion } \\
\text { RMB were issued in March 2009) } \\
-\end{array}$ \\
\hline
\end{tabular}

(Source: Window of China 2009; Naughton 2009) 
This shortfall can in principle be filled by financial resources coming from a mix of local government bonds issued by the central government (or with its approval), corporate bonds, medium-term notes and bank loans (see table 6). However, as China's bond market is still developing, local governments mainly seek their own sources of finance. This article concentrates on the increasing commodification of land as a means to generate income. This is possible because China's land leasehold market was formally established in the late 1970s under Deng Xiao-Ping. Urban land is state-owned but the separation of ownership and landuse rights means that public and private actors can shape its disposition and utilization. Urban land-use rights could be leased for fixed periods (e.g., 70 years for residential housing) at a fee and land-right leases are tradable at auctions. This development encourages local officials to acquire arable land for conversion and re-zoning rural towns as urban by compensating (at least in principle) the communities involved. In this regard, local governments engage in 'land-based finance'. This means that local governments derive extra-budgetary income from intensifying land-based commodification. The latter involves acquiring land, developing land, selling land use rights, collecting fees, obtaining mortgage loans, and acquiring land again (Global Times 2010). ${ }^{9}$ Local governments can thereby generate 'land transfer income' from auctions, land rights licenses, land transfer fees, collateralize mortgage loans, etc. In 2009, it accounted for 46 percent of overall financial revenue of local governments compared with 35 percent in 2001 (Global Times 2010). A complication is that the Budget Law prohibited local governments from raising loans directly. So they established government-run financial vehicles to borrow from large state-owned banks (e.g., Bank of China, China Construction Bank), using land as collateral. Close relations among local governments, their financial vehicles and state-owned banks made credit easily available between 2008 and 2010. During this period, local government debt rose tenfold from 1 trillion RMB (USD 146 billion) to an 
estimated 10 trillion RMB (USD 1.7 trillion) (Xinhua 2011). Concurrently, Bank of China recorded a profit rate of 28 percent year on year for 2010 (Business Weekly 2011).

This monopoly use of land (and land use rights) for generating income and loans means that local governments, property developers and state-owned banks have strong interests in keeping land development active and property prices high. This land-based expansion is reinforced by emerging popular socio-economic attitudes that property ownership is a source of housing, economic security, hedge against inflation, social status, family safety net and personal pride. The business press, media, and peer/family outlooks strengthen these views in everyday life. Indeed, sayings such as 'no car, no house, no bride' are common among women of married age (Offbeat China 2011).The desire for home ownership apart, low interest rates and the absence of a national property tax allowed for speculative property to be purchased and held relatively cheaply. In short, all these public and private land-based calculations have been propelling real estate inflation and fears of a 'property bubble' have revived since 2009. According to Colliers International, residential prices in 70 large- and medium-sized cities across China rose in 2009, with 50 to 60 per cent increases in Beijing and Shanghai. Such increases reduce housing affordability with the conventionally calculated standard residential property price to average annual family income ratio for Beijing being 1:22. This compares with UN's ideal figure between 1:3 and 1:4 (Smith 2010; Powell 2010; FlorCruz 2009).

The inflationary rise of real estate and falling affordability of property have politicized the housing question. This was acknowledged by the Premier Wen when he remarked on 27 February 2010 that 'property prices have risen too fast' and this 'wild horse' must be tamed. The central government leaders introduced regulatory measures in 2010 to dampen the market (e.g., tightening of credit, raising deposits for purchase of new land to 50 per cent; 
restricting the purchase of second and third homes, etc.). However, such stabilization measures have moderate effects and property prices continue to rise in some provinces and cities. The reasons include: (a) banks find other ways to increase their credit (e.g., selling off mortgage loans to state-owned trusts and asset-management companies; turning loans into investment products and selling them to private investors, etc.); and (b) local governments soften up these property investment restrictions and selectively implement local-level initiatives to maintain their land-based mode of accumulation.

This way of organizing the local political economy does not imply unity of purpose among actors. It only means that, for their own particular purposes, they work together at this conjuncture. Specifically, this mode of accumulation generates 8 percent (or higher) growth rates for the central government, jobs, perks and promotion for local officials; revenue, projects and growth statistics for ministries and local governments; profit/investment for state-owned banks and state-owned/private property developers;, and, of course, benefits to property owners (Sum 2011). Such apparent advantages to central-local elites are not matched by benefits elsewhere in the economy and population. Indeed, rising property prices, wealth accumulation and regular land auctions co-exist with social unrest related to land grab, affordability of housing, the plight of 'house slaves', conditions of migrant workers, inflationary pressures, and corruption. These sources of unrest destabilize the society and have markedly uneven impacts upon the socio-economic positions of ordinary citizens and the subaltern groups. The incidence of protests, riots and mass incidents quadrupled between 2000 and 2010 (Orlik 2011). Given that land grab issues and high-profiled resistance cases (e.g., Wukan revolt) are already well-reported in the academic literature (e.g., van Westen 2011; Jiang 2012) and on the Internet (e.g., Wikipedia, Youtube, etc.), ${ }^{10}$ this article turns to two less well-known social issues related to everyday life: the life of 'house slaves' and plight of migrant workers (and children) in rural towns. 
First, the life of 'house slaves' was reflected and popularized in a TV serial entitled Dwelling Narrowness (Snail House) in 2009 (see Image 1). It is based on a novel by Tu Qiao, an independent journalist and writer. The story highlights a couple's struggle to buy an apartment in the midst of rising property prices in a fictional city that could well be Shanghai. Specifically, the story concerns two sisters who have borrowed heavily to buy user rights to an apartment. To obtain the money, one sister begins an affair with a wealthy and corrupt official. He later falls from grace because of a scandal over the diversion of pension funds to finance property projects (He 2009). The story resonated among ordinary people and social critics especially regarding the impact of high property prices upon families and young couples, corruption and cronyism in real estate markets, class disparities and the sexual economy of mistresses. In spite (or perhaps because) of its popularity, the serial was taken off the Beijing TV Youth Channel on 22 November 2009. It was subsequently criticized by the State Administration of Radio, Film and Television as sensationalizing 'sex and corruption for profit'. Nonetheless, its gritty urban actualism continues to appeal and the serial is still available on the Internet and DVD. It has been viewed online and downloaded more than 100 million times on the Internet (Yu 2011) and government officials admitted to having watched it. Like most cultural products, this serial has been interpreted in many ways. One view is that it is a piece of social criticism that sharply depicted the painful everyday life of under-paid university graduates, 'stooges of real estate business' and 'house slaves' (Hung 2011: 165). For example, it signified a life dominated by numbers - the joy of payday, the pain of saving for a flat, and the daily distress of making ends meet. It seems as if these workers do not own their dwelling, but their dwelling owns them and dictates their working lives and family relationship as if it had enslaved them. The serial supplied material for countless newspaper columns, blog and forum discussions as well as appeals for action. Among many responses to this depiction, a Xiamen artist, Li Bing, constructed a 'house slave sculpture' that portrayed a 
man standing on his hands while his body was overloaded with many layers of bricks (Xiamen News 2010).

Image 1 Popular Serial on Dwelling Narrowness (Snail House) 2009

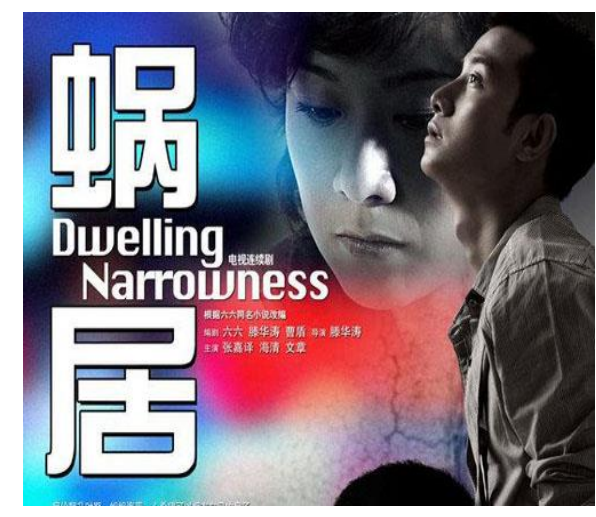

(Source: China.org.cn)

A second, but related, issue is the plight of migrant workers in rural towns on the periphery of cities. These workers comprise a significant part of the reserve army of labour that supports the Chinese export economy and high growth rates. While low and insecure income and lack of household registration entitlements (hukou) ${ }^{11}$ prevent them becoming 'house slaves', they risk becoming displaced by the same property boom dynamic. This accelerates land clearance in rural towns for real estate projects, displaces workers and increases the rent for their accommodation. These effects are so rampant that it has triggered rising social unrest related to land appropriation, under-compensation for land/property seizure, inflation, corruption, etc. Apart from land-based peasant riots, resistance is also expressed through the Internet. An unusual and innovative example of everyday resistance emerged in October 2010. A blogger called Blood Map used Google Map to chart the distribution of sites where there have been land conflicts, use of violence against residents, and people's resistance to illegal land grab and property demolitions in China. ${ }^{12}$ 
Land appropriation and clearance also affect migrant workers, especially their children. Migrant families have no hukou in urban areas and some children go to low-fee schools set up in slums in these rural towns. These provide inexpensive instruction with support from NGOs and community movements. Urban clearance means that this kind of affordable education is vanishing due to school closures. In Beijing alone, migrant schools have fallen from 320 in 2008 to 180 in mid-2012 (Meng 2012). These schools were categorized by the local authorities either as 'unsafe' or 'illegal' (making them ineligible in both cases for compensation on closure). As for the displaced children, a Beijing News survey (2012) showed that 53 percent transferred to other migrant-children schools, 33 percent returned to home villages (some for schooling), 13.6 percent re-registered at government-run schools, and 0.4 percent had parents who had not yet decided what to do. Those re-registered in government-run schools often face discrimination from permanent residents who do not want their children to have classmates whose parents 'sell fish or vegetables'. Children who were sent back to home villages become 'left-behind children' with social concerns related to living with aging relatives or in school dormitories. These issues raise more general questions about the rights of migrant workers and a hukou system that creates second-class citizens in urban areas. Whereas the central government is eager for change; local governments are more reluctant because they must foot the welfare bills especially in times of shortfall. Nevertheless, some cities (e.g., Shanghai) conducted pilot programmes in 2009 to grant 'permanent resident permits' to migrants. Eligibility is narrowly based on a points system related to education, tax payment, criminal record, etc. This creates a stratified citizenship as less than 0.1 per cent of migrants qualify (Kong 2010).

In response to these socio-economic tensions, there are calls to stabilize growth and maintain social stability. Responses include controlling property prices by credit restrictions, lowering the targeted growth rates to 7.5 percent, and reorienting policies for a social agenda (e.g., 
housing, education, etc.). However, tightening of credit is hurting local governments (and related property interests) as their expansion is largely based on collateralized mortgage loans and rising property prices. A credit squeeze means a fiscal crunch for local governments with the result that they resort to heavy-handed means of collecting taxes and selectively modulating the economic and social agenda according to local priorities. As the global financial crisis continues to deepen and the economy experiences slowdown, China, at the time of writing (September 2012), is facing more intense struggles between central government, local governments and the people (especially the subaltern) over issues related to slowing growth, shrinking stimulus package, unemployment, controlling property prices, continuing land-based finance, rising social unrest and maintaining stability.

Although China may have been 'in a class of its own' in recent years, the BRIC quartet does seem to be proceeding towards slowdown in 2012 with the deepening of the crisis. This poses more questions for the well-circulated BRIC investment and the 'decoupling thesis'. Bloomberg reported on 15 June 2012 that O’Neill himself said the situation in China and other BRIC members might be 'more worrisome than the Eurozone crisis' but he also refused to count out the BRIC (just yet). However, the backlash on the BRIC hope is gathering as more negative media headlines (e.g., 'O'Neill's BRIC risk hitting wall threatening G2O growth') appeared. Apart from reimagining BRIC's future, Goldman and some business press are wasting no time to identify new objects of hope: already the MIST bloc (Mexico, Indonesia, South Korea and Turkey) is on the discursive horizon.

\section{Concluding Remarks}

This article uses a CPE approach to examine the discursive-material bases of the development of the BRIC imaginary since 2001. Partly complementing discussions in cultural economy and building on radical political economy and Foucauldian studies of 
governmentality, CPE seeks to connect the micro-macro aspects of political economy by exploring the dialectic of their discursive-material moments, especially as these are created, mediated, and circulated through agency and governmental technologies. This has been illustrated from the construction of BRIC in three overlapping moments, each of which was related to particular material conjunctures - the 9/11 attack, the 2007 financial crisis and its repercussions in China. At each conjuncture, diverse set of (trans-)national agents (e.g., investment banks, think tanks, international organizations, mass media, etc.) were engaged in the making of this imaginary. They are shot through with affective and persuasive energy that link, invent, select and circulate BRIC as an object of 'hope'/'strength'. They experiment with discourses and practices that create a multi-layered discursive space that governs individual and collective decisions as well as commonsensical beliefs in the power of BRIC. Apart from asking 'when' do these discourses gain credence and 'who' gets enrolled in making this 'imagined recovery', a CPE approach also examines 'how' questions. These include how: (a) these processes have been mediated by a wide range of transnational discursive networks; (b) governmental knowledging technologies of power, such as identification, achievement, investability and agency, were deployed to create, privilege and naturalize the BRIC economies as objects of 'hope'/'strength' in the everyday subjectivities of global recovery; and (c) this imagined recovery constructs the BRIC economies as useful 'non-western' consumers and lenders who could drive growth and recovery. However, this is more than a rhetorical process as this imagination has been made more credible, materially, by the BRIC's efforts to stimulate their economies. Within the globalized mode of BRIC knowing, China is singled out as having a 'golden standard' stimulus package in 2008. This helped to sustain the global recovery imaginary; but a CPE approach also inquires into the nature (the 'what') of the struggles and unevenness of this process especially at the nationallocal levels. Using China as an illustration, this article noted that this 'gold standard' 
stimulus package has intensified some deep-rooted tensions within central-local relations. It gave a central-government green light for local governments to bring forward pet projects. Given that these authorities are expected to provide $70 \%$ of the fund, land is increasingly used to leverage loans and raise revenue. Land sales and property development become important investment and speculative activities with consequences such as property bubble, forced displacement from land, peasant riots, state terror, dispossession of the already vulnerable (e.g., migrant children) and increasing inequalities. Such growing social tensions and unevenness characterize, in part, the dark side of the 'shinning BRIC' as sites of investment, consumption and lending. Within the BRIC, China was seen as leader and its vast stimulus package was narrated as important for western recovery and reinvigorated growth. However, such 'hope and energy' needs to be examined together with the 'fear and anger' of the subaltern groups at specific sites as well as the energy of (trans-)national networks turning up more hope objects such as MIST (i.e., Mexico, Indonesia, South Korea, Turkey). In this regard, A CPE approach aims to offer ideological critiques of hegemonic constructions (e.g., BRIC and possibly MIST) based on micro-technologies of power as well as to highlight tensions in some local subaltern social sites (e.g., slum schools, and 'Blood Map'). These are often neglected and glossed over in globalized discourses and practices of imagining crisis recovery and socio-economic changes. 


\section{Acknowledgements}

This article derives in part from research conducted with the support of a British Academy BARDA Award on 'Changing Cultures of Competitiveness' 2008-2010 (No. BARDA-48854). The author also thanks Bob Jessop and three anonymous reviewers for helpful comments and Lo Mo Kwan and Slamet Sawiyah for their domestic support during fieldwork. 


\section{Endnotes}

${ }^{1}$ Sum $(2005 ; 2011)$ outlines six discursive-material moments in the remaking of social relations.

${ }^{2}$ In the light of the deepening financial crisis, a fourth moment has emerged: the construction of 'fear'. Apart from worries about China's and India's locomotive roles, this mainly concerns a feared loss of US competitiveness rooted in 'innovation deficits' aggravated by rising 'frugal innovation' in these countries (see Schmidt 2010).

${ }^{3}$ For Chaput, affect 'acts as an energy moving between human beings via communicative practices that inspire behaviour instinctively' (2010: 7; more generally, 7-12).

4 These growth ingredients evolved into a measurement tool known as the Growth Environment Scores (GES) Indexes by 2005 (for details, see O’Neill 2012).

${ }^{5}$ For details of these products, see http://www2.goldmansachs.com/ideas/brics/index.html, accessed $8^{\text {th }}$ October 2011.

${ }^{6}$ South Africa was included as the fifth member of the BRIC Summit in 2011 in China.

${ }^{7}$ Fundamental differences among the BRIC include diverse political systems, and dissimilar views on key policy issues such as free trade and energy pricing.

${ }^{8}$ As local government debts grew, they were allowed to issue bonds from October 2011 until June 2012.

${ }^{9}$ Wang Xiaoying, a researcher in the Chinese Academy of Social Sciences, described this process in 2010 as "acquiring land, selling land, imposing taxes, mortgage and then acquiring land again" (see http://www.globaltimes.cn/business/china-economy/2010-12/606958.html, accessed $16^{\text {th }}$ August 2012). My account clarifies, builds on, and gives more details.

${ }^{10}$ Wikipedia includes 'Protests on Wukan' (see

http://en.wikipedia.org/wiki/Protests_of_Wukan) an (see

http://en.wikipedia.org/wiki/Protests_of_Wukan) and a Google search on $13^{\text {th }}$ a Google 
search on August 2012 generated 125,000 hits for 'Wukan Revolt' on Youtube, international media and blog sites.

11 Most rural migrants have no hukou in urban areas and no rights to public housing, education for their children or local pension and health care benefits.

12 For details of the 'Blood Map', see 'Elusive "blood map" founder speaks out', http://observers.france24.com/content/20101119-china-evictions-violence-blood-mapgoogle-founder-speaks-out, accessed 14th March 2011. 


\section{References}

Aitken, R. (2007). Performing capital. Basingstoke: Palgrave Macmillan.

Baldwin, C. (2009). China: One bright spot of US companies' results. Retrieved from http://www.reuters.com/article/2009/04/27/us-usa-earnings-china-analysisidUSTRE53Q2DE20090427

Beijing News (2012). Closing down of migrant children schools: 30 percent children returned to home villages (in Chinese). Retrieved from http://news.163.com/12/0827/02/89SNTI4N00014AED.html

Best, J. \& Paterson, M. (Eds.) (2010). Cultural political economy. London: Routledge.

Business Insider (2011). BRICs=Bloody Ridiculous Investment Concepts. Retrieved from http://articles.businessinsider.com/2011-11-30/markets/30457741_1_bric-investors$\underline{\text { markets }}$

Business Weekly (2011). Bank of China posts record profit, drop in bad loans. 24 August, retrieved from http://www.businessweek.com/news/2011-08-24/bank-of-china-postsrecord-profit-drop-in-bad-loans.html

Callon, M. (1998). An essay on framing and overflowing: Economic externalities revisited in Sociology. In M. Callon (Ed.), The Laws of the market (pp. 244-69). Oxford: Blackwell.

Chandler, M. (2009). BRIC or CRIB? Retrieved from http://seekingalpha.com/author/marcchandler/comment/549887

Chaput, K. (2010). Rhetorical circulation in late capitalism: Neoliberalism and the overdetermination of affective energy. Philosophy and Rhetoric, 43(1), 1-18.

Chaudhuri, P. (2012). Why a group of BRICs pledged cash for a wealthier West? Retrieved from http://asiasociety.org/blog/asia/expert-why-group-brics-has-pledged-cashwealthier-west

Connolly, W. (2002). Neuropolitics. Minneapolis, MN: University of Minnesota Press. 
Crotty, J. (2009). The structural causes of the financial crisis. Cambridge Journal of Economics, 33, 536-80.

Cruikshank, B. (1999). The will to empower. Ithaca: Cornell University Press.

de Goede, M. (2004). Repoliticizing financial risk. Economy and Society, 33(2). 197-217.

Drezner, D. J. (2009). BRIC-a-brac. Retrieved

fromhttp://drezner.foreignpolicy.com/posts/2009/06/17/bric-a-brac

Dean, M. (1999). Governmentality: Power and rule in modern society. London: Sage.

Descheneau, P. \& Paterson, M. (2012). Between desire and routine: assembling environment and finance in carbon markets. In P. Newell, M. Boykoff \& E. Boyd (Eds.), The new carbon economy (pp. 65-84). Chichester: Wiley-Blackwell.

FlorCruz, J. (2009). Will the China property bubble pop? Retrieved from http://www.cnn.com/2009/BUSINESS/12/30/china.property.bubble/index.html

Global Times (2010). Land transfer now major source of local governments' fiscal revenues:

A report. Retrieved from http://www.globaltimes.cn/business/china-economy/2010-

$\underline{12 / 606958 . h t m l}$

Goldman Sachs (2001). Building better global economic Brics, London: Goldman Sachs

Global Economic Paper no. 66. Retrieved from

www.goldmansachs.com/our.../brics/brics.../build-better-brics.pdf

Goldman Sachs (2010). Idea Website on BRIC. Retrieved

fromhttp://www2.goldmansachs.com/ideas/brics/index.html

He, H-F. (2009). Rumours swirl as top TV series blacked out. South China Morning Post, 26 November. Retrieved from

http://www.scmp.com/portal/site/SCMP/menuitem.2af62ecb329d3d7733492d9253a0a0a

0/?vgnextoid=1e7f639a40c25210VgnVCM100000360a0a0aRCRD\&ss=China\&s=News 
Hung, R. (2011). The state and the market: Chinese TV serials on the case of Woju (Dwelling Narrowness). Boundary 2, 38, 157-87.

ILO (2009a). China's response to the crisis, G20 Country Briefs. Retrieved from http://www.ilo.org/public/libdoc/jobcrisis/download/g20_china_countrybrief.pdf

ILO (2009b). Brazil's response to the crisis, G20 Country Briefs. Retrieved from http://www.ilo.org/public/libdoc/jobcrisis/download/g20_brazil_countrybrief.pdf

ILO (2009c). Russian Federation's response to the crisis, G20 Country Briefs. Retrieved from, http://www.ilo.org/public/libdoc/jobcrisis/download/g20_russia_countrybrief.pdf Investment U (2009). Profit from the 'new decoupling'. Retrieved from http://www.investmentu.com/IUEL/2009/July/decoupling-emerging-markets.html Jaeger, M. (2008). BRIC as international investors: China in a class of its own. Deutsche Bank Research, Talking Point. Retrieved from http://www.slideshare.net/soniabess/china-as-an-international-investor-in-a-class-of-itsown-presentation

Jessop, B. and Sum, N.L. (2006). Beyond the regulation approach: Putting capitalist economies in their place. Cheltenham: Edward Elgar.

Jiang, X. (2012). China's land grab alchemy. Retrieved from http://thediplomat.com/chinapower/chinas-land-grab-alchemy/

Kannan, P. (2009). National policy responses to economic and financial crisis: The case of India, ILO Regional Office in Asia, Bangkok. Retrieved from http://www.ilo.org/wcmsp5/groups/public/---asia/---robangkok/documents/meetingdocument/wcms_101591.pdf

Kelly, B. (2009). Brazil, Russia, India and China (the BRICs) throw down the gauntlet of the international monetary system. 28 June. Retrieved from 
http://www.eastasiaforum.org/2009/06/28/brazil-russia-india-and-china-the-brics-throwdown-the-gauntlet-on-monetary-system-reform/

Kong, S. (2010). China's migrant problem: The need for Hukou reform. Retrieved from http://www.eastasiaforum.org/2010/01/29/chinas-migrant-problem-the-need-for-hukoureform/

Larner, W. \& Walters, W. (2004). Global governmentality. London: Routledge.

Lordabett.com (2009). Why decoupling should benefit international investors. Retrieved from https://www.lordabbett.com/articles/wp_why_decoupling_should.pdf

Lula da Silva, L. (2010). The BRIC countries comes into their own as global players. Retrieved from http://www.huffingtonpost.com/luiz-inacio-lula-da-silva/the-briccountries-come-i_b_539541.html

Mackenzie, D. (2004). The big, bad wolf and the rational market. Economy and Society, 33(3), 303-34.

MacKenzie, D. (2006). An engine, not a camera: How financial models shape markets. Cambridge MA: MIT Press.

MacKenzie, D., Muniesa, F. \& Sui, L. (2007). Do economists make markets? On the performativity of economics. Princeton: Princeton University Press.

Marinis, A. (2008). BRIC consumers can't hold off world recession. Livemint.com. Retrieved from http://www.livemint.com/2008/12/18211911/Bric-consumers-can8217t$\underline{\text { hol.html }}$

Massumi, B. (n.d.). Full text of interview with Brian Massumi. Retrieved from http://www26.us.archive.org/stream/InterviewWithBrianMassumi/intmassumi_djvu.txt

Mellor, W. \& Lim, L-M. (2008). BRIC shoppers will "rescue world" Goldman Sachs Says. Retrieved from http://www.bloomberg.com/apps/news?pid=newsarchive \&sid=a3aTPjYcw8a8 
Meng, L. (2012). Parents' worry as migrant school faces shut down. Retrieved from http://www.globaltimes.cn/content/717811.shtml

Miller, P. \& Rose, N. (2008). Governing the present. Cambridge: Polity.

Montgomerie, J. (2008). Bridging the critical divide: Global finance, financialization and contemporary capitalism. Contemporary Politics, 14(3), 233-52.

Naughton, B. (2009). Understanding Chinese stimulus package. Chinese Leadership Monitor No. 28, Spring. Retrieved from http://www.hoover.org/publications/clm/issues/44613157.html

Offbeat China (2011). Leftover women in China speak their hearts out 'no car, no house, no bride'. Retrieved from http://offbeatchina.com/leftover-women-in-china-speak-theirheart-out-no-house-no-car-no-bride

O’Neill, J. (2009). The new shopping superpower. Retrieved from http://www.newsweek.com/2009/03/20/the-new-shopping-superpower.html

O’Neill, J. (2012). The growth map. London: Portfolio/Penguin.

Orlik, T. (2011). Unrest grows as economy booms. Retrieved from http://online.wsj.com/article/SB10001424053111903703604576587070600504108.html

Powell, B. (2010). China's property: Bubble, bubble, toil and trouble. 22 March, Retrieved from $\underline{\text { http://www.time.com/time/magazine/article/0,9171,1971284,00.html }}$

Prestowitz, C. (2005) Three billion new capitalists. New York: Basic Books.

Pryke, M. \& du Gay, P. (2007). Take an issue: Cultural economy and finance, Economy and Society, 36(3), 339-54.

Ramesh, J. (2005). Making Sense of Chindia. New Dehli: India Research Press.

Schiff, P. (2008). Little book of bull moves in bear markets. Chichester: Wiley. 
Scher, R. (2009). From BRIC to BIC ... or even to IC?? Retrieved from http://risingpowers.foreignpolicyblogs.com/2009/06/08/from-bric-to-bic\%E2\%80\%A6oreven-icl

Schmidt, G. (2010). Erasing our innovation deficit. Retrieved from http://www.washingtonpost.com/wpdyn/content/article/2010/02/09/AR2010020901191.html

Sharma, R. (2012). Break out nations. Harmondsworth: Penguin.

Sheth, J. (2007) Chindia Rising. New Dehli: Tata McGraw-Hill.

Shinnick, R. (2008). Decoupling thesis intact. Retrieved from http://seekingalpha.com/article/63886-decoupling-thesis-intact

Sidaway, J. \& Pryke, M. (2000). The strange geographies of 'emerging markets'. Transactions of the Institute of British Geographers, 25(2), 187-201.

Slater, D. (2002). From calculation to alienation: Disentangling economic abstractions. Economy and Society, 31(2), 234-49.

Smith, C. (2010). Global economy's next threat: China's real estate bubble. Retrieved from http://www.dailyfinance.com/story/global-economys-next-threat-chinas-real-estatebubble/19302329/\#

Song, Y. (2010). Framing China under global financial crisis. Paper for Annual Meeting of the International Communication Association, Singapore, 22 June 2010. Retrieved from http://www.allacademic.com/meta/p403482_index.html

Sum, N-L. (2005). Discourses, material power and (counter-)hegemony Retrieved from http://www.lancaster.ac.uk/cperc/research.htm

Sum, N-L. (2010). The production of hegemonic policy discourses: 'Competitiveness' as a knowledge brand and its (re-)contextualizations. Critical Policy Studies, 3(1), 50-76. 
Sum, N-L. (2011). Financial crisis, land-induced financialization and the subalterns in China. In C. Scherrer (Ed.), China's labour question (pp.199-208). Berlin: Springer-Verlag.

Sum, N-L. \& Jessop, B. (2006). Towards a cultural international political economy: Poststructuralism and the Italian School. In M. de Goede (Ed.), International Political Economy and Post-Structural Politics (pp. 157-76). Basingstoke: Palgrave Macmillan.

Sum, N-L. \& Jessop, B. (2013). Towards a cultural political economy. Cheltenham: Edward Elgar (forthcoming).

Tett, G. (2010). The story of the Brics. Retrieved from http://www.ft.com/cms/s/2/112ca932$\underline{00 a b-11 d f-a e 8 d-00144 f e a b d c 0 . h t m l}$

Van Westen, A.C.M. (2011). Land in China: Reform and struggles. Development, 54(1), 5558.

Wheatley, A. (2011). BRICS sign framework pact for local-currency credit lines. Retrieved from http://www.reuters.com/article/2011/04/14/brics-credit-idUSL3E7FE0AV20110414

Wilson, D. and Purushothaman, R. (2003). Dreaming with the BRICs. Goldman Sachs Global Economic Research Website, Global Economic Paper No. 99. Retrieved from http://www2.goldmansachs.com/ideas/brics/brics-dream.html

Xi, S., Zhang, X-D. \& Cheng, Z-Y. (2009). Mitigating debt bomb for Chinese local governments. Economic Observer, 1 June. Retrieved from http://www.eeo.com.cn/ens/finance_investment/2009/06/01/138892.shtml

Xiamen News (2010). 'House Slave Sculpture' in Xiamen street sparks heated discussion. Retrieved from http://www.whatsonxiamen.com/news_msg_cn.php?titleid=14865

Xinhua (2011). China's local government debts exceed 10t Yuan. Retrieved from http://www.chinadaily.com.cn/bizchina/2011-06/27/content_12786826.htm

Yu, H. (2011). Dwelling narrowness: Chinese media and its disingenuous neoliberal logic. Continuum: Media and Cultural Studies, 25(1), 33-46. 